\title{
ASSOCIATIVE AND GENDER ASPECTS OF THE EMOTIONAL CONCEPT OF JEALOUSY IN THE UKRAINIAN LINGUISTIC CULTURE
}

\author{
Olena Petiak \\ ORCID: 0000-0002-0635-493X \\ lenapetyak@gmail.com \\ Khmelnytskyi National University, Ukraine
}

Received March 1, 2020; Revised May 30, 2020; Accepted June 23, 2020

\begin{abstract}
The article deals with the associative and gender features of the perception by marriage partners of the emotional concept of "jealousy" within the framework of the Ukrainian linguistic culture. Associative and gender features of the studied concept were found out as a result of data analysis of free word association test held with 100 Ukrainian speaking students, graduate students, and teachers (50 men and 50 women) at Khmelnytskyi National University, Ukraine. The respondents were in official marriage; their age was from 18 to 65. With the help of the free word association test the connections of the concept of "jealousy" in the Ukrainian language consciousness and the semantic zones of this stimulus word were determined. An important step was to take into account the opinions of the researchers regarding the possible difference between manifestations and the emergence of jealousy in men and women. Psycholinguistic ideas about jealousy are manifested in the ambivalence of emotions, the semantic clues of which are the polar properties of "love" ("care") - "hatred" (“doubt”, "suspicion”). The gender factor affects the structure of the associative field of the concept of "jealousy" and determines both its quantitative indicators and its "semantic content". Qualitative analysis of the results of the free word association test helped to separate male and female world images and made it possible to talk about gender stereotypes regarding jealousy in the everyday linguistic consciousness of marriage partners.
\end{abstract}

Keywords: word association test, jealousy, concept, linguistic culture.

Анотація. У статті йдеться про асоціативні та гендерні особливості сприйняття шлюбними партнерами емоційного концепту «ревнощі» в межах української лінгвокультури. Дослідження проводилось серед студентів, викладачів та співробітників Хмельницького національного університету, які перебувають в статусі офіційного шлюбу. За допомогою вільного асоціативного експерименту визначені зв'язки концепту «ревнощі» в українській мовній свідомості, смислові зони даного слова-стимулу. Важливим етапом було врахування думок досліджуваних стосовно qмовірної різниці між проявами та виникнення ревнощів у чоловіків та жінок. Психолінгвістичні уявлення про ревнощі виявляються в амбівалентності емоцій, семантичними ознаками якої є полярні властивості «кохання» («турбота») - «ненависть» («сумнів», «підозра»). Гендерний чинник має вплив на структуру асоціативного поля концепту «ревнощі» та зумовлює і кількісні показники в структурі організації асоціативного поля концепту, і його «семантичне наповнення». Якісний аналіз результатів вільного асоціативного експерименту допоміг сформувати окремі фрагменти чоловічої і жіночої картин сприйняття світу в мовній свідомості та дав можливість розмірковувати про гендерні стереотипи стосовно ревнощів у повсякденній мовній свідомості шлюбних партнерів.

\footnotetext{
(C) Petiak, Olena, 2020. This is an Open Access article distributed under the terms and conditions of the Creative Commons Attribution 4.0 International Licence (http://creativecommons.org/licenses/by/4.0).

East European Journal of Psycholinguistics, 7(1), 140-145. https://doi.org/10.29038/eejpl.2020.7.1.pet
} 
Ключові слова: асоціативний експеримент, ревнощі, конщепт, лінгвокультура, ревнощуі.

\section{Introduction}

Jealousy is one of the most destructive phenomena in the history of mankind connected with the sphere of family relationship. It has been present in the minds of people for the whole period of human history. The features of the phenomenon of jealousy lie in its multi-componentiality, since the attempts to explain it are integrated in the field of various fields of science, particularly, psychology, psycholinguistics, cultural studies, etymology, philosophy, religion, ethics, sociology (Pines, 1992). Jealousy is associated with mistrust, various types of aggression - verbal, physical, hostile, instrumental (Havryliv, 2019), envy, greed, perseverance, temper, paranoia, selfishness, sex (Shevtsov, Hupalovska, 2020), and love. Ambivalence and uncertainty of jealousy are deeply rooted in the public consciousness of many peoples, including the Ukrainian ethnos (Terekhova, 2018), and are reflected in some Biblical excerpts (Men, 2018). With the spread of jealousy at certain stages of human development, the researchers concluded that it is traced in the cultures where gender differentiation is encouraged (Foucault, 2000).

Jealousy is characterized by a combination of negative emotional states that arise when you lose the ability to own something or someone. They have historically determined roots, since each culture contains regulations on what should be unquestionably owned by a person and should be divided. Therefore, the causal field of jealousy of one culture will not necessarily cause jealousy among representatives of other cultures. Jealousy is what a person feels who passionately wants to own the object of his love or affection without separation and at the same time experiences fear of loss. As Rubinstein stated, in jealousy passionate love is combined with fierce hatred (Rubinstein, 2006, p. 511), experiencing jealousy is so strong that it's sometimes stronger than the feeling of love itself.” (Ilyin, 2007, p. 346). The motive for jealous relationships is the fact "that someone loves not us but somebody else (or pretends to annoy or bring sufferings to a partner)" (Ilyin, 2007). Fromm believed that stubborn madness and fixation on each other is not at all proof of the power of love, but only indicates immeasurable preliminary loneliness (Fromm, 1995).

Thus, among basic feelings which accompany jealousy are fundamental emotions of fear and anger: the fear to lose a valuable relationship and a feeling of being safe, the anger is present, because someone else is considered to be better than the person - object of jealousy (Isard, 2002). Consequently, jealousy is a combination of love, hatred, envy, fear, and anger. But if love is excluded, then every meaning of jealousy is lost. Due to this love can be defined as a key pretext for jealousy and the main communicative linguistic category. Jealousy is considered to be an aspect of love, its secondary structure, its sub-category. Marital jealousy occupies a peculiar place (Isard, 2002; Maslow, 2008), as it is in "the middle" of hatred and love. To be faithful in love themselves (to destroy the idea of infidelity even in your thoughts) or to cope with jealousy, the person needs to have some life 
experience and mature soul, self-sustainability and a balanced psyche which means self-actualization (Maslow, 2008, p. 214). It should be mentioned that those people don't need each other in general understanding as average lovers: they may be very close but may separate without any harm to themselves or a partner when it is necessary. Self-actualized personalities may enjoy the communication with each other and be ready "to philosophically accept long separation" at the same time. (Maslow, 2008, p. 220).

Jealousy is a complex, ambivalent feeling that a person experiences, requires exceptional loyalty and devotion to only one, and truly or falsely doubts them. This feeling arises when the personality is suspicious that they are deprived of the monopoly for love and loyalty of a person from whom they expect it (Kubryakova, 1995). The emotional concept of "jealousy" is the result of a person's complex cognitive and emotional mastery of linguistic and non-linguistic reality. The dialectical understanding of this phenomenon, that is, the interpretation of the cultural space, involves the use of not only linguistic, but also psychological, historical, social, general cultural data that modern science has (Khomulenko, Kuznetsov, 2019). Jealousy is a mental structure, reinterpreted in Ukrainian linguistic culture and is updated in the national consciousness in certain social conditions (Kristjansson, 2002).

\section{Methods}

The relevance of the study is explained by the need to investigate the associative-gender aspects of the emotional concept of "jealousy" as an element of the ethnic identity (Lyubimova, 2017) of a linguistic personality. The purpose of this research was to define the associative semantic space content of jealousy as reflected in male and female linguistic consciousness of the Ukrainian participants in marriage. Thus, associative and gender features of the emotional concept of "jealousy" were explored as a result of data analysis of free word association test held with 100 Ukrainian speaking students, graduate students, and teachers (50 men and 50 women) at Khmelnytskyi National University (Ukraine). The respondents were in official marriage; their age was from 18 to 65 . The results of this study reflect gender differentiation, since there is sexual proportionality of the respondents.

To receive efficient results of free association test, we created a two-part questionnaire. The first part contained "introductory" questions (age, gender, marital status, official marriage duration) necessary to define the age and social group of the research objects. The second part contained three stages where the respondents had to:

1. indicate the first five associations which come to their mind as a response to the "jealousy" word-stimulus;

2. write down first five reactions which come to their mind as a response to "a jealous person” expression; 
3. answer a question if there is any difference in male and female jealousy experience; if the difference exists, demonstrate how it is revealed and demonstrated.

When interpreting the results of free word association test and other questions of the questionnaire, the received data was consolidated to define the semantic core of the associations.

\section{Results and Discussion}

Table 1 shows the results of the study.

Table 1

Results of word association test

Associative responses of respondents to the words-stimuli “jealousy" and "jealous"

\begin{tabular}{|c|c|c|c|}
\hline \multicolumn{2}{|c|}{ Word-stimulus "jealousy" } & \multicolumn{2}{|c|}{ Word-stimulus “jealous” } \\
\hline Reaction & Amount (\%) & Reaction & Amount (\%) \\
\hline Mistrust & 32.0 & Man & 15.8 \\
\hline Black color & 19.2 & Owner & 8.5 \\
\hline Anger & 1.4 & Angry & 12.0 \\
\hline Bad feeling & 6.3 & Othello & 8.5 \\
\hline Fear & 2.3 & Egoist & 6.8 \\
\hline Hatred & 6.0 & Mistrustful & 32.0 \\
\hline Evil & 2.0 & Rough & 6.0 \\
\hline Uncertainty & 13.8 & Individualist & 3.0 \\
\hline Ownership & 17.0 & Aggressive & 7.4 \\
\hline
\end{tabular}

The results obtained from the first and second stages of the word association test research show that jealousy is represented as a negative phenomenon associated with mistrust (32.0\%), black color (19.2\%), anger (1.4\%), bad feeling (6.3\%), fear (2.3\%), hatred (6.0\%), evil (2.0\%), uncertainty (13.8\%) and ownership (17.0\%). A group of respondents $(1.6 \%)$ believe that jealousy provides incentives for the feelings, provokes passion in the relationships. Respondents wrote the following associations with the word stimulus "a jealous person": a man (15.8\%), owner/master (8.5\%), angry (12\%), Othello (8.5\%), egoist (6.8\%), mistrustful (32\%), rough (6\%), individualist (3.0\%), aggressive (7.4\%).

The question about the difference between male and female jealousy demonstrated that $72 \%$ of respondents reject the probability of its existence. It means that there is no difference between male and female jealousy. The rest of respondents (28\%) believe that this difference lies mainly in the individual features of jealousy and in the fact that women have mostly emotional manifestations of jealousy, while men - mostly behavioral. Thus, respondents believe that jealous men being owners by nature do not want to share their beloved wife with anyone. At the same time, as it turned out, male jealousy is painful: men do not hide their 
jealousy from partners. Female jealousy, as respective respondents reported, is cruel, emotional, aggressive, evil, insidious, women have more reasons for jealousy (imaginary or real). They are able to revenge on their rival, being more agile in the ways to be jealous or hide this feeling.

\section{Conclusions}

The results of our research show that the emotional concept of "jealousy" plays a role in the Ukrainian linguistic culture. The study confirmed that the concept of "jealousy" is ambivalent, but more often negatively marked ethical phenomenon that has a range of semantic features. The concept is a complex mental construct having its linguistic expression and ethno-cultural specifics. Universal features of jealousy are manifested when implemented in scientific discourse uncovering its essential characteristics.

The conceptualization of jealousy in the minds of contemporary Ukrainians is similar to the general scientific and ethical, philosophical, and religious understanding of this phenomenon by other peoples. Jealousy is associated with the notions of "love”, "mistrust”, "negative feeling”, "uncertainty", "anger”. It was found out that general understanding of the concept by married partners is connected with age, education and personal occupation.

Among common gender features revealed for jealousy, as reported by the participants, were "feeling of anger", "desire to own their partner without sharing", "indignation”, "insult”, "mistrustfulness", "anger”, "hesitations in fidelity and love”, "fear of loss". The gender factor affects the structure of the associative field of the concept by determining both its quantitative indicators of the concept and its "semantic content". Qualitative analysis of the results of the free word association test helped to separate male and female world images and made it possible to talk about gender stereotypes regarding jealousy in the everyday linguistic consciousness of marriage partners.

\section{References}

Гаврилів О. Непряма вербальна агресія. East European Journal of Psycholinguistics. 2019.

T. 6, № 2. C. 7-20. https://doi.org/10.5281/zenodo.3637704

Изард К. Э. Психология эмоций. Нижний Новгород : Питер, 2002.

Ильин Е. П. Эмоции и чувства. С.-Петербург : Питер, 2016.

Кубрякова Е. С. Начальные этапы становления когнитивизма: лингвистика - психология когнитивная наука. Вопросы языкознания, 1995. № 4. С. 3-15.

Маслоу А. Мотивация и личность. Москва: Питер, 2008 .

Мень А. Мировая духовная культура. Нижний. Новгород: Нижегородская ярмарка, 1995.

Рубинштейн С. Л. Основы общей психологии. Санкт-Петербург: Питер, 2006.

Фромм Э. Состояние человека. Москва: Смысл, 1995.

Фуко М. Історія сексуальності. Харків : Око, 2000.

Хомуленко Т., Кузнецов А. Психолингвистическое значение концепта «вера».

Psycholinguistics-Psiholingvistika. 2019. Вип. 25, № 1. С. 338-362.

Шевцов А., \& Гупаловська В. Психосемантичний зміст поняття сексуальності в мовній свідомості дорослих. Psycholinguistics-Psiholingvistika, 2020, Bun. 27, № 1. С. 310-334. https://doi.org/10.31470/ 2309-1797-2020-27-1-310-334. 
Pines A. (1992). Romantic Jealousy: Understanding and Conquering the Shadow of Love. New York: St. Martin's Press.

Kristjansson K. (2002). Justifying Emotions: Pride and Jealousy. L.: Routledge.

Lyubimova, S. (2017). Etymological memory of a word in designating sociocultural stereotype. East European Journal of Psycholinguistics, 4(1), 140-149. https://doi.org/10.5281/zenodo.821718

Terekhova, D. (2018). An experimental study of the lingual consciousness of Ukrainians and Russians (Dynamic aspect). East European Journal of Psycholinguistics, 5(1), 92-110. https://doi.org/10.5281/zenodo.1436306

\section{References (translated and transliterated)}

Havryliv, O. (2019). Nepriama verbalna agressiya [Indirect verbal aggression]. East European Journal of Psycholinguistics, 6(2), 7-20. https://doi.org/10.5281/zenodo.3637704.

Izard, K. E. (2002). Psikhologiya Emotsii [Psychology of Emotions]. Nizhny Novgorod: Piter, 446.

Ilyin, E. P. (2016). Emotsii i Chuvstva [Emotions and Feelings]. S.-Petersburg: Piter.

Kubryakova, E. S. (1995). The initial stages of the formation of cognitivism: linguisticspsychology-cognitive science. Voprosy Linguistiki, 4, 3-15.

Maslow, A. (2008). Motivatsiya i Lichnost [Motivation and Personality]. Moscow: Piter.

Men, A. (1995). Mirivaya Dukhovnaya Kultura [World Spiritual Culture]. Nizhny Novgorod: Nizhegorodskaya Yarmarka.

Rubinstein, S. L. (2006). Osnovy Obshchey Psikhologii [Fundamentals of General Psychology]. S.-Petersburg: Piter.

Fromm, E. (1995). Sostoyaniye Cheloveka [The Human Condition]. Moscow: Sense.

Foucault, M. (2000). Istoriya Sexualnosti [The History of Sexuality]. Kharkiv: Oko.

Khomulenko, T., Kuznetsov, A. (2019). Psycholinguistic meaning of the concept of "Faith". Psycholinguistics-Psiholingvistika, 25(1), 338-362. https://doi.org/10.31470/2309-17972019-25-1-338-362.

Shevtsov, A., \& Hupalovska, V. (2020). Psychosemantic content of the concept of sexuality in the linguistic consciousness of adults. Psycholinguistics-Psiholingvistika, 27(1), 310-334. https://doi.org/10.31470/2309-1797-2020-27-1-310-334.

Pines, A. (1992). Romantic Jealousy: Understanding and Conquering the Shadow of Love. New York: St. Martin's Press.

Kristjansson, K. (2002). Justifying Emotions: Pride and Jealousy. L.: Routledge.

Lyubimova, S. (2017). Etymological Memory of a Word in Designating Sociocultural Stereotype. East European Journal of Psycholinguistics, 4(1), 140-149. https://doi.org/10.5281/zenodo.821718.

Terekhova, D. (2018). An Experimental Study of the Lingual Consciousness of Ukrainians and Russians (Dynamic Aspect). East European Journal of Psycholinguistics, 5(1), 92-110. https://doi.org/10.5281/zenodo.1436306. 